\title{
A tool to analyse gender mainstreaming and care-giving models in support plans for informal care: case studies in Andalusia and the United Kingdom
}

\author{
María del Mar García-Calvente, Esther Castaño-López, Inmaculada Mateo-Rodríguez, Gracia \\ Maroto-Navarro, María Teresa Ruiz-Cantero
}

J Epidemiol Community Health 2007;61(Suppl II):ii32-ii38. doi: 10.1136/jech.2007.060665

See end of article for authors' affiliations

Correspondence to: Maria del Mar GarcíaCalvente, Escuela Andaluza de Salud Pública, Campus Universitario de Cartuja, Apartado de Correos 2070, E-18080 Granada, Spain: mariadelmar.garcia.easp@ juntadeandalucia.es

Accepted 10 July 2007

\begin{abstract}
Objective: To present a tool to analyse the design of support plans for informal care from a gender perspective, using the plans in Andalusia and the United Kingdom as case studies.

Methodology: A tool was drawn up to analyse gender mainstreaming and care-giving models involved in the documents. In the gender mainstreaming aspect, a symbolic dimension (gender mainstreaming in the plan's theoretical framework and analysis of situation) and an operational dimension (gender mainstreaming in the plan's proposals and actions) were defined. Four care-giving models were analysed using the following categories: the plan's definition of carer, focal point of interest, objectives and acknowledgement or otherwise of conflict of interests. A qualitative discourse analysis methodology was used.

Results: The analysis tool used shows that the plans do not incorporate gender mainstreaming systematically, but there are interesting aspects from a gender perspective that are present at both a symbolic and an operational level. Both plans use a combination of care-giving models, but the model for superseding informal care is not included in either plan.

Conclusions: The proposed tool proved useful for the examination of the gender perspective in the formulation of the plans selected for analysis. Both plans introduce measures to improve the quality of life of informal carers. However, gender mainstreaming also implies interventions that will change situations of sexual inequality and injustice that occur in informal care in the long term. Likewise, aspects of feminist theory must be considered in order to draw up plans and policies that are sensitive to informal care and the emancipation of women carers.
\end{abstract}

nformal care has been defined as unpaid care provided by family, friends or other individuals to people who are restricted in the activities of daily living. ${ }^{1}$ Informal care is a public health phenomenon that takes place all over the world. In Spain there are 3.5 million people over the age of 6 who are dependent, $80 \%$ of whom receive care solely from their family. ${ }^{2}$ In the United Kingdom there are six million carers ${ }^{3}$; similar proportions have been observed in other countries in Europe ${ }^{4-6}$ and worldwide. ${ }^{7-10}$

Carers often have no choice when they take on the responsibility of providing care, and this factor has a negative impact on carers' health. Caring can also have a positive impact, ${ }^{11}$ although it also causes stress, social isolation, physical and mental problems, and limits the possibilities of working. ${ }^{12}{ }^{13}$ Many studies show the different consequences of caring on carers' health and quality of life, ${ }^{14-16}$ and even on their mortality. ${ }^{17}$

If gender is added as a variable, informal care is characterised by inequality and unfair gender based division of work. Over $75 \%$ of informal carers worldwide are women ${ }^{24810}$; they spend more hours providing care than men, help with a greater number of tasks, care for individuals with more severe behavioural problems, they are more overburdened and suffer more depression, and show lower levels of wellbeing and physical health. ${ }^{18}$ The responsibility of informal care is taken up by women, ${ }^{19}$ who largely carry the role of main carer ${ }^{10} 2021$ and also secondary carer. $^{22}$ Approaching informal care from a feminist perspective is an urgent issue in view of its impact on women's health and wellbeing, the little research that is available on gender sensitive problems of informal carers, ${ }^{23}$ the lack of acknowledgement of women carers' social and economic contributions, invisibility of care, ${ }^{22}$ the tendency to feminise and naturalise caring skills and rejection of women carers' $^{\prime}$ expertise. ${ }^{24}$

Few European countries have laid down national strategies for informal carers' services, despite their implications in health, social, labour and economic policies. Of the different welfare state models in Europe, ${ }^{25}$ the Mediterranean prototype is characterised by an unequal development of public policies, major gaps in care services and family support to complement government action. ${ }^{26}$ In Spain, coverage provided by community services is scarce, women are the sole carers of their dependent relatives and the majority of services offered are focused on covering the basic needs of dependent people with limited resources. ${ }^{2} 16$

At present, Andalusia is the only region in Spain that has a support plan for family carers, ${ }^{27}$ although the new national dependency law includes some indirect measures aimed at carers. ${ }^{28}$ In the rest of Europe, the United Kingdom is the only country with a national plan for informal carers. ${ }^{29}$ Several countries include measures aimed at carers in their plans for the care of dependent people, such as respite care services, pension credits or payments for carers. ${ }^{30}$ Other countries, such as those in Scandinavia, actually have many services to support informal carers but, because of the decentralised and local character of this system, these services have not been documented at a national level.

Policies developed in this area in any type of welfare state will lead to different care-giving models, depending on the focus and aims of the interventions. ${ }^{31}$ Each model has different implications in terms of gender according to how the needs and interests of carers are viewed. As a result, a superseded carer 
model would be more positive in terms of gender equality than a model of the carer as a resource. Measures to support carers should take into consideration the unequal distribution of responsibilities and burden between family and state, and between different members of the informal network (women and men). Social policies may have positive and negative consequences that are not equally distributed between women and men, or between women themselves. ${ }^{32}$ Gender mainstreaming is the (re)organisation, improvement, development and evaluation of policy processes, so that a gender equality perspective is incorporated in all policies at all levels and at all stages. $^{33}$ Focusing on that, we need to examine how the drawing up of informal care policies affects women and men. ${ }^{34}$ Gender analysis is a central part of this process and it provides a useful instrument for health planning, ${ }^{35-38}$ integrating gender mainstreaming into public policies ${ }^{39-41}$ and assessing its impact on gender equity. ${ }^{42}{ }^{43}$

The objective of this paper is to present a tool to analyse the design of support plans for informal care in Europe from a gender perspective, using the plans in Andalusia and the United Kingdom as case studies.

\section{METHODOLOGY}

In order to analyse the design of plans for informal care from a gender perspective, an "ad hoc" tool has been created that examines mainstreaming and the care-giving models involved. The tool has been designed by the authors and is based on categories proposed in the bibliographical references regarding the gender perspective in health planning, ${ }^{34} 3538$ gender mainstreaming in policies and programmes, 3336373940 gender based analysis, ${ }^{41}$ evaluation of the impact of gender ${ }^{42}{ }^{43}$ and caregiving models. ${ }^{31}$ In order to analyse gender mainstreaming, two dimensions were defined and broken down into categories (table 1): a symbolic dimension (theoretical framework and analysis of the situation as drawn up by the plan) and an operational dimension (proposals and actions defined in the plan). The following factors were examined in the symbolic dimension: incorporation of the gender perspective in the concepts, values and main sectors of the plan; the inclusion in the analysis of the data after it is broken down and interpreted according to sex and the specific requirements of female carers; and input from experts in gender issues as well as carers in the design of the plan. The operational dimension took into account

Table 1 Definition of categories for the analysis of gender mainstreaming in support plans for informal carers

\begin{tabular}{|c|c|}
\hline \multicolumn{2}{|l|}{ Symbolic contents of the plan } \\
\hline \multicolumn{2}{|l|}{ Theoretical framework } \\
\hline Gender perspective at a formal level & $\begin{array}{l}\text { Governing principles that stress the need to incorporate a gender focus into the } \\
\text { development of policies, action lines and measures drawn up to support informa } \\
\text { carers }\end{array}$ \\
\hline Existing knowledge & $\begin{array}{l}\text { Consultation of recently published scientific studies that show evidence of } \\
\text { feminisation of informal care and its impact on women's health }\end{array}$ \\
\hline Consultation with experts & $\begin{array}{l}\text { The plan has been written with the collaboration of experts in gender issues and } \\
\text { informal care }\end{array}$ \\
\hline Consultation with carers & Informal carers have participated in designing the plan \\
\hline Expertise & $\begin{array}{l}\text { The expertise of carers is respected with regard to caring for the dependent } \\
\text { person }\end{array}$ \\
\hline Sexual division of work & $\begin{array}{l}\text { Carers' work is made visible; sexual, patriarchal separation of care tasks is } \\
\text { denounced }\end{array}$ \\
\hline Carers' contribution & $\begin{array}{l}\text { The social and historical contribution of women carers is made visible in terms of: } \\
\text { (1) the cost of care in market terms; (2) time saved by relatives who do not provide } \\
\text { care; (3) cost of women carers' lost opportunities; (4) social benefit reaped }\end{array}$ \\
\hline Women's right not to provide care & $\begin{array}{l}\text { Acknowledgement that: ( } 1 \text { ) informal care is not a natural skill; (2) the government } \\
\text { must support dependent individuals; ( } 3 \text { ) women (or other family members) are no } \\
\text { obliged to care for their relatives but they do have the duty to love them }\end{array}$ \\
\hline \multicolumn{2}{|r|}{ 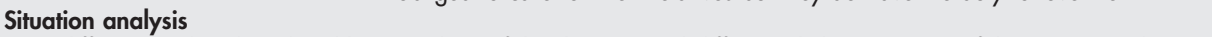 } \\
\hline $\begin{array}{l}\text { Data differentiated and analysed by } \\
\text { sex }\end{array}$ & $\begin{array}{l}\text { Analysis of the diversity and differential characteristics of the carer population, } \\
\text { according to social class and other variables }\end{array}$ \\
\hline Women carers' needs & $\begin{array}{l}\text { Consideration is taken for women carers' specific needs as women: reproduction, } \\
\text { lower salaries, gender bias in social health care, double shifts (at home and at } \\
\text { work); caring for the rest of the family who are not dependent }\end{array}$ \\
\hline \multicolumn{2}{|l|}{ Operational content of the plan } \\
\hline \multicolumn{2}{|l|}{ Proposals } \\
\hline Gender focused objectives & $\begin{array}{l}\text { Objectives established that are based on the actual difference between women } \\
\text { and men carers, which seek to meet their specific needs, extend cover of services } \\
\text { for this population group and improve their health and quality of life }\end{array}$ \\
\hline \multicolumn{2}{|l|}{ Actions } \\
\hline $\begin{array}{l}\text { Positive actions that equalise, } \\
\text { promote and transform }\end{array}$ & $\begin{array}{l}\text { Mediation with regard to gender stereotypes and sexist social practices that } \\
\text { reproduce unequal and discriminatory situations that have to be confronted by } \\
\text { informal women carers }\end{array}$ \\
\hline Strategic interests & $\begin{array}{l}\text { Development of long term interventions to bring about gender sensitive structura } \\
\text { changes and lead to real equal opportunities in the field of informal care }\end{array}$ \\
\hline Daily interests & $\begin{array}{l}\text { Development of gender focused functional changes that are plausible on a shor } \\
\text { term, in order to improve the daily lives of informal women carers }\end{array}$ \\
\hline Individual, non-subrogated rights & $\begin{array}{l}\text { Support measures for informal care that are independent for the carer, and } \\
\text { unrelated to the family and to dependent individuals }\end{array}$ \\
\hline Gender budget & Incorporation of the gender perspective into financing of measures \\
\hline Transparency & Justification of interventions by means of data broken down by sex \\
\hline Differential impact & Separate evaluation of the plan's impact for women and for men carers \\
\hline Equivalent benefits & $\begin{array}{l}\text { Interventions on the different starting points of women and men carers in order to } \\
\text { correct unequal situations }\end{array}$ \\
\hline
\end{tabular}


the formulation of objectives aimed at gender equality and the proposal of actions and strategies to promote equal opportunities and equality between men and women in relation to informal care.

Four care-giving models ${ }^{31}$ were defined using the following analysis categories: the plan's definition of carer population, its main focus (dependents and/or carers), objectives in terms of informal care, and acknowledgement or otherwise of potential conflicts of interest between dependants and their carers: carers as a resource, co-worker, co-clients and superseded carer models.

The support plans for informal care in Andalusia ${ }^{27}$ and the United Kingdom ${ }^{29}$ have been examined using a qualitative discourse analysis methodology. After homogenising criteria and testing the team analysis tool, the two plans were fully reviewed by two members of the team using the categories described above as a reading guide, and "yes" and "no" were used as the possible responses for each category. Any differences in opinion among the researchers were resolved via discussion until a consensus was reached. It was established that gender mainstreaming and the predominance of each caregiving model were in direct proportion to the number of items with affirmative answers. The results of the analysis are presented using literal quotations, and the plan and the page number where the text cited appear in the document analysed are provided in parentheses.

\section{RESULTS}

\section{Gender mainstreaming at a symbolic level}

The symbolic content of the two plans analysed reveal major gaps in gender issues (table 2). Neither of the plans identify governing principles within a theoretical framework that promote non-sexist forms of caring, experts in gender issues and care have not participated in writing the plans and there is no analysis of carers' historical contribution to society's welfare.

In fact, both documents implicitly hold women's increasing participation in the labour market as being responsible for today's problems in caring for dependent individuals (table 3, UK p20, Andalusia p4), rather than seeing this as an advantage that also finally helps to draw attention to an unjust situation that has been hidden under the veil of domestic work.

Women's right not to be carers is not explicitly examined in either of the plans. However, the UK plan suggests a hypothetical freedom to choose whether to become an informal carer (UK p83). Likewise, in its Carer's Rights Decalogue, the Andalusia plan provides for the possibility that a carer may refuse to comply with certain demands (Andalusia p13).

Both the Andalusia and UK plans acknowledge at some point the knowledge and expertise of carers (UK p37). The Andalusia plan mentions, in its references, awareness of feminisation and the impact of caring on women's health, and it consulted women carers themselves by means of focus groups with patients and their families in order to draw up measures

Table 2 Gender mainstreaming of the support plans for informal care in the UK and Andalusia: symbolic contents and operational contents

\begin{tabular}{|c|c|c|}
\hline Symbolic contents & UK & Andalusia \\
\hline \multicolumn{3}{|l|}{ Theoretical framework } \\
\hline Governing principles that promote non-sexist ways of caring for dependent persons & No & No \\
\hline Knowledge of feminisation and its impact on informal carers' health & No & Yes \\
\hline Consultation with experts in gender issues and informal care & No & No \\
\hline Consultation with informal carers themselves & No & Yes \\
\hline Acknowledgement of women carers' expertise & Yes & Yes \\
\hline Visibility of the sexual distribution of care tasks & No & No \\
\hline Visibility of the economic, social, and historical contribution of women carers & No & No \\
\hline Women's right not to provide care & * & * \\
\hline \multicolumn{3}{|l|}{ Situation analysis } \\
\hline Informal care data broken down by sex & No & Yes \\
\hline Informal care data analysed by sex & No & No \\
\hline Informal care data on diversity and vulnerability & * & No \\
\hline Informal care data on whether carers live with the dependent person & * & No \\
\hline Informal care data on relationships & * & Yes \\
\hline Impact of informal care on health and quality of life & Yes & Yes \\
\hline Informal care burden & Yes & Yes \\
\hline $\begin{array}{l}\text { Carers' needs: reproduction; double shifts; lower salaries; caring for the rest of the } \\
\text { family; gender bias in social health care }\end{array}$ & No & No \\
\hline \multicolumn{3}{|l|}{ Operational contents } \\
\hline \multicolumn{3}{|l|}{ Proposals } \\
\hline $\begin{array}{l}\text { Objectives to overcome gender inequalities and imbalances between women and men } \\
\text { carers }\end{array}$ & No & No \\
\hline Objectives to supersede the informal care situation & No & No \\
\hline Objectives on women and men carers' specific needs & Yes & Yes \\
\hline Objectives regarding healthcare coverage for carers & Yes & Yes \\
\hline Objectives to improve carers' health & Yes & Yes \\
\hline \multicolumn{3}{|l|}{ Actions } \\
\hline Positive actions that equalise, promote and transform & Yes & * \\
\hline Daily interests & Yes & Yes \\
\hline Strategic interests & No & No \\
\hline Individual, non-subrogated rights & Yes & * \\
\hline Budgets that are sensitive to gender and informal care & No & No \\
\hline Justification of interventions with data broken down by sex & No & No \\
\hline Evaluation of the differential impact of the plan for women and men carers & No & No \\
\hline Equivalent benefits for women and men carers & No & No \\
\hline
\end{tabular}


Table 3 Gender mainstreaming of the support plans for informal care in the UK and Andalusia: literal quotations*

\begin{tabular}{|c|c|}
\hline Plan for informal care in UK & Plan for informal care in Andalusia \\
\hline $\begin{array}{l}\text { Symbolic level } \\
\text { "Social trends may affect the supply of care. Increased } \\
\text { participation of women in the labour market might be } \\
\text { thought to result in a reduction in the supply of people able } \\
\text { to care" (p20) } \\
\text { "We intend to make progress so that more carers feel } \\
\text { prepared and equipped to care if that is what they choose } \\
\text { to do" (p83) } \\
\text { "People who need care and the people caring for them } \\
\text { know most about their own circumstances... we should } \\
\text { recognise their expertise, perspective and circumstances... } \\
\text { when informing carers about services health and local } \\
\text { authorities need to listen first to what carers have to say" } \\
\text { (p37) } \\
\text { Operational level } \\
\text { "Government will publicise the benefits of carer friendly } \\
\text { employment policies... will promote the adoption of good } \\
\text { practice" (p31) } \\
\text { "Many carers at present lose the opportunity to make } \\
\text { proper provision for their retirement because their working } \\
\text { lives are interrupted by a period of caring. In the case of } \\
\text { women this may be a second interruption of employment, } \\
\text { following one they have already taken to bring up children. } \\
\text { In future, time spent caring will qualify carers to entitlement } \\
\text { to a second pension" (p35) } \\
\text { "Many carers have expressed concern about lack of } \\
\text { recognition of the role of the carer in hospital settings... } \\
\text { carers must be fully informed and involved in the planning } \\
\text { of the future of the patient, so that assumptions are not } \\
\text { made about their ability or willingness to care (...) where } \\
\text { carers need more specialist information or help from other } \\
\text { agencies, such as social services, NHS Direct will be able to } \\
\text { refer callers onto other sources of help" (p42) } \\
\text { "Carers have a right to see their own health needs met" } \\
\text { (p55) }\end{array}$ & $\begin{array}{l}\text { "Changes in the family's structure or organisation, } \\
\text { especially if it loses a member, if the woman finds } \\
\text { employment or the family members live far apart from } \\
\text { each other, are all factors which reduce the availability of } \\
\text { family carers (...)" (p4) } \\
\text { "[Carer's Rights Decalogue] Say NO to excessive, } \\
\text { inappropriate or unrealistic demands" (p13) } \\
\text { "Using the focus groups carried out by the EASP } \\
\text { (Andalusian School of Public Health) involving Andalusian } \\
\text { families and patients as a sample, the general } \\
\text { expectations of female family carers are (...)" (p10) }\end{array}$ \\
\hline
\end{tabular}

(Andalusia p10). Although the UK plan did not consult the carer population, it does encourage health professionals to listen to carers' demands.

With regard to the situation analysis, the British plan does not break down or analyse data by sex, although it does discuss the diversity of carers with regard to whether the carer lives with the dependent person, her/his relationship with the latter, the carer's burden and impact of caring on her/his health. The Andalusia plan does indeed present data by sex in association with relation and impact of care on the carer's health, although these factors are not analysed from a gender perspective. Neither of the documents analysed takes into account carers' needs related to subordination or sexual discrimination regarding their position in society.

\section{Gender mainstreaming at an operational level}

Yet again, there are major gaps in gender issues in the operational contents of the documents analysed (table 2). Neither plan establishes objectives to overcome sexual inequality between women and men carers or to encourage formal as opposed to informal care. Objectives related to specific needs of the carer population, health service coverage and improved carer health are detailed in both documents. However, the two plans focus these objectives on a different target population: women carers in the case of the Andalusia plan, and carers of both sexes as one group in the case of the British plan.

Both documents establish positive actions. In the case of Andalusia the aim of these actions is not to overcome sexual inequalities but to give priority to the most overburdened women carers (table 3, Andalusia p24). The UK plan differs in this aspect, because it promotes labour policies that are sensitive to family life in order to contribute to changing some carers' situations (UK p31). Similarly, provision is made to protect the social security contributions of people who leave their jobs in order to care (UK p35).

Both documents take into consideration the daily interests of the population to which they are addressed (Andalusia pl6; UK p42), but strategic interests to reverse women carers' unequal, unjust situation are neglected in both cases. Both the Andalusia and the British plans acknowledge, at some point, the individuality of carers' rights (UK p55; Andalusia pl4). However, the Andalusia plan establishes services for carers that in fact are subrogated to caring for the dependent person: flexibility of hours, facilitating access to health system and support workshops. These issues are all directly related to the quality of care of dependent individuals.

The incorporation of the gender perspective is a pending subject in the two plans with regard to the drawing up of budgets and evaluation.

\section{Care-giving models}

Both plans use a combination of care-giving models, incorporating characteristics from the resource, co-worker and co-client models (table 4).

The Andalusia plan incorporates the co-client model when the interest is focused on carers (table 5, Andalusia p5) and when a general objective is established explicitly for this population group (Andalusia p14). However, partial acknowledgement of a conflict of interests reveals elements of the coworker model (Andalusia p9), which leads to a new objective 
Table 4 Care-giving models identified in support plans for informal care in the UK and Andalusia

\begin{tabular}{|c|c|c|c|}
\hline Model & Characteristics & UK & Andalusia \\
\hline \multirow[t]{4}{*}{ Carers as resource } & $\begin{array}{l}\text { Very broad definition of carers: any person in the community or } \\
\text { family who provides help }\end{array}$ & Yes & No \\
\hline & The focal point of interest is the dependent person & Yes & Yes \\
\hline & $\begin{array}{l}\text { The objective is to maximise informal care and minimise changes } \\
\text { in carers }\end{array}$ & Yes & No \\
\hline & $\begin{array}{l}\text { The conflict of interests between care givers and recipients is } \\
\text { ignored }\end{array}$ & No & Yes \\
\hline \multirow[t]{4}{*}{ Carers as co-workers } & $\begin{array}{l}\text { The definition of carers is broad: people in the community or } \\
\text { family who help as principal carers }\end{array}$ & No & No \\
\hline & $\begin{array}{l}\text { The focal point of interest is the dependent person and the } \\
\text { instrumental interest is in carers }\end{array}$ & Yes & Yes \\
\hline & $\begin{array}{l}\text { The objective is to maximise quality of informal care by means of } \\
\text { the carer's wellbeing }\end{array}$ & Yes & Yes \\
\hline & $\begin{array}{l}\text { There is partial acknowledgement of the conflict of interests } \\
\text { between care providers and recipients }\end{array}$ & Yes & Yes \\
\hline \multirow[t]{4}{*}{ Carers as co-clients } & The definition of carers is restricted to main carers only & No & Yes \\
\hline & Interest is focused on carers & Yes & Yes \\
\hline & The objective is to achieve carers' wellbeing & Yes & Yes \\
\hline & $\begin{array}{l}\text { The conflict of interest between care providers and recipients is } \\
\text { only acknowledged in one direction }\end{array}$ & Yes & No \\
\hline \multirow[t]{4}{*}{ Superseded carer } & $\begin{array}{l}\text { There is no definition of carers because the term is not used. } \\
\text { People are referred to as relatives and friends }\end{array}$ & No & No \\
\hline & $\begin{array}{l}\text { The focal point of interest lies in dependent individuals and carers } \\
\text { as separate entities }\end{array}$ & No & No \\
\hline & $\begin{array}{l}\text { The objective is to achieve the dependent person's independence } \\
\text { and the carer's wellbeing as two separate objectives }\end{array}$ & No & No \\
\hline & $\begin{array}{l}\text { There is a two directional acknowledgement of those who } \\
\text { provide care and those who receive it }\end{array}$ & Yes & No \\
\hline
\end{tabular}

that is implicit and more instrumental: to maximise the quality of care by ensuring carers' wellbeing. The health system needs women carers, and it proposes to involve them in the healthcare process, training them in order to guarantee quality care and their ongoing involvement (Andalusia p19). Furthermore, elements from the carer resource model can be observed among the measures offered to women carers. For example, workshops on carers' skills are proposed, in which the interest lies in the care recipient's wellbeing, ignoring any possible conflict of interest with women carers (Andalusia p33).

The UK plan acknowledges the valuable role that informal care plays in dependent people's health and for the government, and states that carers represent a very useful resource (table 3, UK pl1). The focal point of interest rests implicitly on

Table 5 Care-giving models identified in support plans for informal care in the UK and Andalusia: literal quotations*

\begin{tabular}{|c|c|}
\hline Plan for informal care in the UK & Plan for informal care in Andalusia \\
\hline $\begin{array}{l}\text { "Without this extensive caring, many more elderly, frail, sick or } \\
\text { disabled people would need the support of the statutory services, } \\
\text { and might need to enter a residential or nursing home or into } \\
\text { hospital. This might be a detriment to the quality of life for some } \\
\text { people needing care, and would be at considerable cost to the } \\
\text { taxpayer" (pl 1) } \\
\text { "Caring for carers is a vital element in caring for those who need } \\
\text { care" (p4) } \\
\text { "To support carers in caring out their caring responsibilities... } \\
\text { services providers must see carers as partners in the provision of } \\
\text { help to the person needing care, and must involve them as } \\
\text { partners. Carers need the help of the statutory services - working } \\
\text { together-to provide the best possible care" (p45) } \\
\text { "Individual assessment of carer's needs is intended to allow } \\
\text { service providers to judge the state of their health, their needs } \\
\text { and wishes, and their ability to continue to care if that is what } \\
\text { they want to do, or to bring informal caring to an end" (p38) } \\
\text { "We want to enhance the quality of life for carers. This means } \\
\text { finding ways to give them: freedom to have a life of their own; } \\
\text { time for themselves; opportunity to continue to work; control over } \\
\text { their life; better health and well-being; integration into } \\
\text { community; peace of mind" (p83) } \\
\text { "We want to strike the right balance. By empowering carers we } \\
\text { are not taking away any rights of the people who need care... } \\
\text { our policies and procedures should ensure the both people in the } \\
\text { caring relationship are valued. We must not subordinate the } \\
\text { needs and wishes of one part to those of the other" (pl4) }\end{array}$ & $\begin{array}{l}\text { "Involve the family carer in the patient's care plan } \\
\text { and (...) especially with interventions that will } \\
\text { guarantee training in basic management of the } \\
\text { patient's health situation" (p19) } \\
\text { "[The objective] is to develop knowledge, skills and } \\
\text { attitudes that will improve the quality of care provided } \\
\text { to dependent persons [the content] ageing; pressure } \\
\text { sores; hygiene; nutrition; elimination; mobility; } \\
\text { warning signs; medicines" (p33) }\end{array}$ \\
\hline
\end{tabular}

*The page number where the text cited appear in the document analysed 
the dependent people and instrumentally on their carers (UK p4). As a result, the general objective of this plan is based on the carer as co-worker model (UK p45). There are also elements from the co-client model, when at certain moments the point of interest rests solely on carers (UK p38), and the carers' wellbeing is established as one of the objectives of the plan (UK p83). Exceptionally, the British policy acknowledges a conflict of interests in both directions, which is a necessary step in order to overcome the "conflictive" relation between those who provide and receive informal care (UK p14). However, this subject is barely touched upon, since no objectives are established in order to overcome the interdependent relationship between carers and dependent individuals.

\section{DISCUSSION}

The analysis tool that we used has enabled us to explore gender mainstreaming and care-giving models in the design of support plans for informal care. In view of the results, we can confirm that the plans reviewed are not committed to overcoming gender inequalities in the informal care of dependent individuals. The predominant care models used, together with the absence of gender sensitive elements, reflect the lack of commitment shown by both documents with regard to this objective.

However, the plans do deal with a major problem suffered by society in general and women in particular. Women not only provide most of the care, they also require more care than men. ${ }^{4}$ For this reason, we are delighted that the two plans have been written and services have been implemented to support dependent individuals and their carers.

On the other hand, they are also a great source of controversy. The Andalusia plan deals solely with women carers, presuming that caring is carried out by women only. The gender utility of this approach lies in the aim to watch over the daily welfare of women carers. However, it does not encourage men to participate in these activities; it does not seek to liberate women carers or for the latter to play a full part in society. ${ }^{44}$ The British document, however, addresses the carer population as if it was a homogeneous group-that is, assuming that there is a similar proportion of women and men carers and that they all have identical needs. In short, it removes the gender issue from the problem of carers. However, the British distribution of roles and tasks differs from the Spanish context. In the United Kingdom, women and men provide care in a more balanced proportion, although women spend more hours providing care. ${ }^{45}$ In Spain, however, a greater proportion of carers are women and there is a special concept of the government's and families' responsibilities in managing daily life. ${ }^{46}$

Both approaches are of some interest from a feminist perspective: in view of the fact that the majority of carers are women, it is important to make their contribution visible, and meet their immediate needs. However, it is also essential not to feminise the problem. Carers should arise from the whole of the population and care should be viewed as everyone's responsibility. In this respect, there is a priority in proposing measures that will facilitate the large scale incorporation of men carers, and other measures that will guarantee care provision for dependent individuals as an individual right, regardless of whether they have an informal care network or not. The documents that we have analysed do not comment on this issue. So what happens to the strategic interests of the carers, dependent individuals and society as a whole, from a gender perspective?

As the results show, the plans we analysed are not based on a care model that seeks to replace informal care. From a feminist point of view, this means that although the two governments are aware of the problem, neither has delved into the sexist

\section{What is already known on this subject}

Dependent individuals' care is largely taken on by women in the former's immediate informal network. Care-giving can have negative consequences on carers' health and quality of life. Unequal distribution of burdens, responsibilities and consequences of informal care among women and men presents significant gender inequality in Western societies. Despite this, there are few public policies that deal with meeting the needs of carers in European countries. Support measures for informal carers are often drawn up from a gender blind perspective.

\section{What does this study add?}

This investigation proposes an instrument to systematically examine gender mainstreaming and care-giving models involved in drawing up support plans for informal carers. The two case studies analysed reveal that the incorporation of the gender perspective in support plans for informal care-giving still has major gaps, from a symbolic angle and also with regard to objectives and actions proposed. Public policies need to be drawn up on caring for dependent individuals and for their carers that are not only gender sensitive but also gender transformative, in order to reduce the inequalities that are currently suffered in informal care.

dynamic of care-that is, they have not got to the root of the problem. The implicit goal of these plans is to ensure that informal care continues, by maintaining the carer as a resource and co-worker models, at the same time converting the carer into a client in order to protect her/his health and to make sure she/he continues caring. This means falling back into a situation in which sexist roles are supported in the main informal carer sector-the family.

Continuing informal care is not an advantage for dependent individuals either; it sustains the myth of family life as a pacific, unselfish system of relations, based on love and solidarity. ${ }^{44} 46$ Both documents assume, as Western patriarchal societies do in general, that their own family or community will best attend people who need care, because the relationships at these levels are ruled by love and sympathy. However, caring for a dependent relative is not something that women always do voluntarily; it may not be a pleasure and it may not necessarily be done willingly.

Informal care implies a great saving in social expenditure in developed countries. ${ }^{47}$ Informal care services, largely carried out by women, would have a very high market value. ${ }^{45}$ Governments are aware of this saving and, in the best of cases, establish support programmes in order to guarantee future continuity of informal care, thus "caring for carers"; in the worst of cases, they do nothing. If the economic costs of potential formal care of dependent individuals are very high, so also are the opportunity costs of informal carers, and the impact that caring has on their health. ${ }^{48}$

The current situation of inequality in informal care is not sustainable on a long term, despite caring more and more for 
women carers. Different organisations are warning about the bleak future of "family" care of dependent individuals, because an increasing number of persons need care, and there are a falling number of people available to provide care. In this respect, the only truly effective solution on a long term, that is gender sensitive, is the acknowledgement of an individual's right to receive care when he/she is dependent, guaranteed through the provision of universal public services.

\section{ACKNOWLEDGEMENTS}

The authors are grateful to Concha Colomer Revuelta for her confidence in this project. We also thank Daniel La Parra and Ana María García for their valuable feedback on the document, which has been exceedingly useful.

\section{Authors' affiliations \\ María del Mar García-Calvente, Esther Castaño-López, Inmaculada} Mateo-Rodríguez, Gracia Maroto-Navarro, Escuela Andaluza de Salud Pública, Granada, Spain

María del Mar García-Calvente, Inmaculada Mateo-Rodríguez, Gracia Maroto-Navarro, María Teresa Ruiz-Cantero, Red de Investigación en Salud y Género, Instituto de Salud Carlos III, Ministerio de Sanidad y Consumo, Spain

María Teresa Ruiz-Cantero, Medicina Preventiva y Salud Pública, Universidad de Alicante, Alicante, Spain

Funding: The Women's Health Observatory of the Ministry of Health and Consumer Affairs, Spanish Government, financed this investigation.

Competing interests: none.

\section{REFERENCES}

1 Australian Institute of Health and Welfare. Carers in Australia: assisting frail older people and people with a disability, Cat No AGE 41. Canberra: AlHW (Aged Care Series) [serial online] 2004, [Accessed 14 June 2006] Available:http://www.aihw.gov.au/publications/age/cia/cia.pdf.

2 Ministerio de Trabajo y Asuntos Sociales. Libro blanco sobre la atención a las personas en situación de dependencia en España 2004. [Accessed 7 Nov 2006] Available from: URL: http://www.tt.mtas.es/periodico/serviciossociales/ 200501/libro_blanco_dependencia.htm.

3 Doran T, Drever F, Whitehead M. Health of young and elderly informal carers: analysis of UK census data. BMJ 2006;327:1388-94

4 Mestheneos E, Triantafillou J. Supporting family carers of older people in Europe. The Pan-European Background Report. Münster: Lit Verlag, 2005.

5 Gräßel E. Häusliche Pflege demenziell und nicht demenziell Erkrankter. Teil I: Inanspruchnahme professioneller Pflegehilfe. Z Gerontol Geriat 1998;31:52-6.

6 Sundström G, Johansson L, Hassing L. The shifting balance of long-term care in Sweden. The Gerontologist 2002:42:350-5.

7 Jenkins A, Rowland F, Angus P, et al. The future supply of informal care, 2003 to 2013: alternative scenarios, AlHW cat no AGE 32. Canberra: AlHW, [serial online] 2003.[Accessed 14 June 2006] Available from:http:// www.aihw.gov.au/publications/age/fsic03-13/fsic03-13.pdf

8 Administration on Aging. The Older Americans Act. National family caregiver support program. Compassion in action, US Department of health and human services.2004. [Accessed 9 May 2006] Available from, http://www.aoa.gov/ prof/aoaprog/caregiver/careprof/progguidance/resources/ FINAL\%20NFCSP\%20Report\%20July22,\%202004.pdf.

9 Administration on Aging. The Older Americans Act. National family caregiver support program. Executive Summary, US Department of health and human services, 2003. [Accessed 9 May 2006] Available from, http://www.aoa.gov/ prof/aoaprog/caregiver/overview/overview_caregiver.asp.

10 Health Canada. Informal/family caregivers in Canada caring for someone with a mental illness - final report. Toronto: Decima Research INC, 2004.

11 López J, López-Arrieta J, Crespo M. Factors associated with the positive impact of caring for elderly and dependent relatives. Arch Gerontol Geriatr 2005;41:81-94.

12 Hirst M. Health inequalities and informal care: end of project report. York: Social Policy Research Unit, 2004.

13 Pirraglia PA, et al. Caregiver burden and depression among informal caregivers of HIV-infected individuals. J Gen Intern Med 2005;20:510-4.

14 Barrow S, Harrison RA. Unsung heroes who put their lives at risk? Informal caring, health and neighbourhood attachment. I Public Health (Oxf) 2005; $27: 292-7$.

15 Takahashi M, Tanka K, Miyaoka H. Depression and associated factors of informal caregivers versus professional caregivers of demented patients. Psychiatry Clin Neurosci 2005:59:473-80.

16 García-Calvente MM, Mateo I, Gutiérrez P. Cuidados y Cuidadores en el sistema informal de Salud. Granada: EASP, 1999.

17 Schultz R, Bech SR. Caregiving as a risk factor for mortality. The caregiver health effects study. JAMA 1999;282:2215-9.
18 Pinquart $M$, Sorensen S. Gender differences in caregivers stressors, social resources, and health: an updated meta-analysis. J Gerontol B Psicol Sci Soc Sci 2006:61:33-45.

19 Rodríguez P. El problema de la dependencia en las personas mayores. Documentación Social 1998;112:33-63.

20 Durán MA. Los costes invisibles de la enfermedad. Bilbao: Fundación BBVA, 2002.

21 La Parra D. Contribución de las mujeres y los hogares más pobres a la producción de cuidados de salud informales. Gac Sanit 2001;15:498-505.

22 García-Calvente MM, Mateo I, Maroto G. El impacto de cuidar en la salud y la calidad de vida de las mujeres. Gac Sanit 2004;18(suppl 2):83-92.

23 Morris M. Gender sensitive home and community care and caregiving research: a synthesis paper, 2001 [Accessed 7 Nov 2006] Available from: http:// www.cewh-cesf.ca/PDF/health_reform/synthesis.pdf.

24 Esteban ML. Cuidado y salud: costes en la salud de las mujeres y beneficios sociales. In: SARE: Cuidar cuesta. Bilbao: Emakunde, 2003.

25 Esping-Andersen G. Three worlds of welfare cpitalism. New Jersey: Princeton University Press, 1990.

26 Blossfeld P, Drobnič S. Careers of couples in contemporary societies. From male breadwinners to dual earner families. Oxford: Oxford University Press, 2001.

27 Junta de Andalucía. Consejería de Salud, Plan atención a cuidadoras familiares en Andalucía. 2005. [Accessed 5 May 2006] Available from: http:// www.sas.junta-andalucia.es/principal/ documentosAcc.asp?pagina $=$ pr cuidadoras

28 Ministerio de Trabajo y Asuntos Sociales. Anteproyecto de ley de atención a las personas en situación de dependencia. Madrid: MTAS, 2006.

29 United Kingdom Government. The national strategy for carers. 1999. [Accessed 5 May 2006] Available from, http://www.carers.gov.uk/pdfs/Care.pdf.

30 Organization for Economic Co-operation and Development. The OECD Health Project. Long-term care for older people. Paris: OECD Publishing, 2005.

31 Twigg J, Atkin K. Carers perceived. policy and practice in informal care. Buckingham: Open University Press, 1994.

32 Amstrong $\mathbf{P}$, Amstrong $\mathrm{H}$. Thinking it through: women, work and caring in the new millennium, 2001. [Accessed 3 Dec 2006] Available from, http:// www.medicine.da.ca./mcewh.

33 Council of Europe. Gender mainstreaming: cnceptual framework, methodology and presentation of good practices, Final report of Activities of the Group of Specialist on Mainstreaming (EG-S-MS).Strasbourg 1998. [Accessed 25 Mar 2007] Available from, http://www.coe.int/ $t / e /$ human_rights/equality/ 02. gender_mainstreaming/1100_EG-S-MG(1998)2rev.asp.

34 Peiró R, Ramón N, Álvarez-Dardet C, et al. Sensibilidad de género en la formulación de planes de salud en España. Gac Sanit 2004;18(suppl 2):36-46.

35 Donner L. Including gender in health planning. A guide for regional health authorities. Prairie Women's Health Centre of Excellence. 2003. [Accessed 22 Feb 2006] Available from: http://www.uwinnipeg.ca/admin/vh_external/ pwhce/pdf/gba.pdf

36 Emakunde. Guía Metodológica para integrar la perspectiva de género en proyectos y programas de desarrollo. Vitoria-Gasteiz: Secretaría general de acción exterior. 1998 [Accessed 25 Nov 2006] Available from: http:// www.emakunde.es/images/upload/guia_cast.pdf.

37 Medical Women's International Association. Training manual for gender mainstreaming in health, 2002. [Accessed 10 Apr 2006] Available from, http:// www.mwia.net/gmanual.pdf.

38 WHO. Integración de las perspectivas de género en la labor de la OMS. Política de la OMS en materia de género. 2002. [Accessed 22 Feb 2006] Available from: http://www.who.int/gender/documents/sppolicy.pdf.

39 El proyecto europeo MAGEEQ. Mainstreaming y políticas de igualdad de género en la Unión Europea. Herramienta para el análisis de género. 2005. [Accessed 11 Apr 2006] Available from: http://www.ucm.es/info/mageeq/ herramienta.htm.

40 Instituto de la Mujer. Guía para la incorporación de la igualdad de oportunidades en las actuaciones de los fondos estructurales. Madrid: Secretaría General de Asuntos Sociales. Ministerio de Trabajo y Asuntos Sociales. [serial online] 2004. [Accessed 7 Nov 2006] Available from: http://www.mtas.es/ mujer/politicas/guiaincorporacion.doc.

41 Morris M. Gender-based analysis: when, how and why. An introductory manual on gender-based analysis for policy analysts and managers at HRDC. Canada: Perspectives Research and Communications for Human Resources Development Canada Women's Bureau, 1996.

42 Lombardo $\mathrm{E}$. Criterios para la evaluación del impacto de género de las medidas políticas. 2005 [Accessed 15 Jul 2006] Available from: http:// www.ceiich.unam.mx/genero/conapo/genero-7.html.

43 Comisión Europea. Guía para la evaluación del impacto de género. [serial online] 2004. [Accessed 15 Jul 2006] Available from: http://europa.eu.int/ comm/employment_social/gender_equality/docs/gender/gender_es.pdf.

44 Izquierdo MJ. Del sexismo y la mercantilización del cuidado a su socialización: hacia una política democrática del cuidado. In: SARE: Cuidar cuesta. Bilbao: Emakunde, 2003

45 Hirst M. Transition to informal care in Great Britain during the 1990. J Epidemiol Community Health 2002:56:579-87.

46 Bover AB, Gastaldo D. The centrality of the family as a resource for homecare: gender and generational perspectives. Res Bras Enferm 2005;58:9-16.

47 Yoo BK, Bhattacharya J, Garber AM. Impacts of informal caregiver availability on long-term care expenditures in OECD countries. Health Serv Res 2004;39:1971-92.

48 Carmichael F, Charles S. The opportunity costs of informal care: does gender matter? J Health Econ 2003;22:781-803. 